\title{
Analisis Manajemen Resiko Aplikasi SIPP di Pengadilan Negeri Salatiga Kelas 1B Mengunakan ISO 31000
}

\author{
Ryan Haryo Pangestu1, Ariya Dwika Cahyono², Penidas Fiodinggo \\ Tanaem $^{3}$ \\ 1,2,3 Information System Departement, Satya Wacana Christian University, Salatiga, \\ Idnonesia \\ Email: 1682017098@student.uksw.edu, 2ariyadc@uksw.edu, \\ 3penidas.fiodinggo@uksw.edu
}

\begin{abstract}
SIPP application is a case tracing information system whose function is to provide information to the general public or severe parties concerned with the case and the information contained in sipp has been adjusted to the applicable regulations. In implementing the information system there must be risks that hinder the process of the system, so here is required risk analysis aimed at preventing or minimizing the risks that will occur. By using ISO 31000 at salatiga district court office, it is expected to minimize the possibility of risks that will occur around SIPP application. The results will be from iso 31000 risk analysis in the form of a document of possible risks that occur around sipp application, grouping the possible risks and their impacts. So that the results of this research can be useful for the salatiga district court office to prevent or at least minimize the risks that may occur in the SIPP application.
\end{abstract}

Keywords: ISO 31000, SIPP Application, Risk Management.

\section{PENDAHULUAN}

Di zaman yang modern sekarang ini perkembangan teknologi berkembang sangat pesat dan dari seluruh aspek kehidupan yang ada hampir sangat bergantung dengan yang namanya teknologi informasi begitu juga dengan Pengadilan Negeri salatiga, perkambangnya teknologi tersebut ditunjang dengan aplikasi yang ada di pengadilan negeri salatiga yang membantu pegawai dalam melakukan pekerjaan mengenai perkara dan masyarakat yang ingin mencari informasi mengenai perkara, tetapi juga setiap aplikasi 
Journal of Computer and Information Systems Ampera

Vol. 2, No. 1, January 2021 e-ISSN: 2775-2496

https://journal-computing.org/index.php/journal-cisa/index

mempunyai dampak negatifnya seperti kejahatan online atau hacker dan carding pada sebuah aplikasi. Maka dari itu perlu di lakukan analisi manajemen resiko di aplikasi tersebut secara berkala agar bias meminimalisir kesalahan-kesalahan yang ada seperti program atau bug serta kelemahan pada program aplikasi, yang bertujuan untuk mengetahui kelemahan atau kemungkinan resiko-resiko yang terjadi di aplikasi dan memberikan saran dan rekomendasi dari kemungkinan resiko-resiko yang akan terjadi.

Sistem Informasi Penelusuran Perkara (SIPP) merupakan sebuah aplikasi berbasis web di Pengadilan Negeri Salatiga kelas 1B yang berfungsi untuk menginput informasi - informasi yang berkaitan dengan perkara seperti data umum, penetapan jadwal untuk sidang, penetapan hakim siapa yang akan memimpin siding, penetapan panitera pengganti, kemudian juga bisa sebagai informasi bagi masyarakat yang mungkin berhubungan dengan perkara dan masyarakat yang terkena tilang juga bisa langsung mengecek denda tilangnya di SIPP Pengadilan Negeri Salatiga kelas 1B.

Dengan adanya aplikasi SIPP pasti memiliki kemungkinan resiko-resiko yang akan terjadi di kemudian hari yang akan mengganggu proses aplikasi tersebut tidak berjalan atau berfungsi dengan optimal. Berdasarkan permasalahan tersebut, maka diperlukan penelitian mengenai kemungkinan resiko-resiko yang akan terjadi pada aplikasi SIPP di kemudian hari. Untuk meminimalisir kemungkinan resiko tersebut maka dilakukan penelitian analisis manajemen resiko menggunakan ISO 31000. Penelitian mengunakan ISO 31000 pernah dilakukan oleh Angraini, Indri Dian Pertiwi pada suatu perusahaan dan hasilnya terdapat 13 resiko diantaranya 6 resiko tinggi salah satunya koneksi jaringan terganggu dan SOP DCRM tidak sepenuhnya diterapkan,6 resiko sedang,1 resiko rendah yang dapat berdampak pada perusahaan tesebut[1].

Berdasarkan penelitian dari Grialdo Willy Lantang dkk (2019) pada PT Serasi Autoraya terdapat 15 resiko yang berpotensi menggangu kinerja aplikasi SAP diantaranya terdapat 2 resiko tinggi(high) seperti koneksi internet putus dan listrik mati, 7 resiko sedang(moderate), 6 resiko rendah(low)[2]. Kemudian penelitian selanjutnya juga pernah dilakukan oleh Fawwaz Afif Alvian dkk (2020) tentang analisis manajemen resiko mengunakan ISO 31000 pada Universitas Islam Negeri Sunan Ampel Surabaya dan hasilnya terdapat 8 resiko tinggi (high) salah satunya yaitu tidak stabilnya listrik pada laboratorium biologi yang dikarenakan adanya 


\section{Journal of Computer and Information Systems Ampera}

Vol. 2, No. 1, January 2021 e-ISSN: 2775-2496

https://journal-computing.org/index.php/journal-cisa/index

UPS,3 resiko sedang (moderate),1 resiko rendah(low) agar resiko tersebut dapat dihindari diperlukan perlakuan pada masing-masing tingkat resikonya[3].

Berdasarkan penelitian diatas bahwa terdapat hubungan dengan penelitian yang akan dilakukan penulis yaitu analisi manajemen resiko pada aplikasi Sistem informasi Penelusuran Perkara (SIPP) di Pengadilan Negeri Salatiga menggunakan analisis resiko ISO 31000 yang bertujuan menganalisis resiko yang mungkin akan muncul, dampak dari resiko itu sendiri, tingkat resiko, dan tindakan terhadap kemungkinan resiko-resiko yang ada pada aplikasi SIPP sehingga Pengadilan Negeri Salatiga dapat melakukan pencegahan sebaik mungkin sehingga kemungkinan resikoresiko tersebut tidak terjadi dan mengganggu proses kinerja kantor.

\section{METODE}

Metode yang di gunakan dalam penelitian ini yaitu metode kualitatif yang dimana metode kualitatif merupakan suatu cara yang digunakan untuk menjawab masalah penelitian yang berkaitan dengan data berupa narasi yang bersumber dari aktivitas wawancara, pengamatan, pengalian dokumen[4].

\subsection{METODE PENELITIAN}

Kemudian pada penelitian ini dilakukan analisis resiko mengunakan International Organization for Standardization (ISO 31000) pada aplikasi SIPP di Pengadilan Negeri Salatiga. ISO 31000 merupakan standar yang berkaitan dengan manajemen risiko yang dimodifikasi oleh International Organization for Standardization (ISO) atau Organisasi Internasional untuk Standarisasi. Tujuan dari ISO 31000 sendiri adalah untuk memberikan prinsip-prinsip dan pedoman untuk manajemen risiko yang di akui secara universal[5]. Di dalam ISO 31000 atau international Organization for Standardization pada gambar 1 menjelaskan susunan kerangka kerja dari manajemen resiko secara universal yang dimana terdapat 2 tahap dalam proses analisis manajemen resiko.

Tahap pertama yaitu penilain resiko(risk assessment) yang di dalamnya lagi ada 3 proses yaitu Identifikasi resiko(risk identification), Analisis resiko(risk analysis), Evaluasi resiko(risk evaluation). Identifikasi resiko adalah usaha untuk menemukan atau mengetahui resiko-resiko yang akan 
Journal of Computer and Information Systems Ampera

Vol. 2, No. 1, January 2021 e-ISSN: 2775-2496

https://journal-computing.org/index.php/journal-cisa/index

timbul pada proses bisnis perusahaan atau organisasi. Identifikasi resiko biasanya dilakukan pada semua proses bisnis yang ada pada sebuah organisasi atau perusahaan. Hal ini memiliki tujuan untuk mengetahui semua resiko-resiko yang timbul dari berbagai faktor, faktor tersebut bisa dari faktor manusia, faktor sistem yang diimplementasikan pada perusahaan atau organisasi, dan bisa jadi faktor dari insfrastruktur[6]. Identifikasi resiko ini dilakukan pada aplikasi SIPP di Pengadilan Negeri Salatiga kelas 1B.

Analisis resiko merupakan sebuah kajian yang penting untuk menjamin keberhasilan proyek sesuai dengan tujuan yang telah ditetapkan, terutama untuk mendukung kegiatan-kegiatan pengembangan[7]. proses analisis resiko pada penelitian ini berfokus pada menentukan resiko-resiko yang berpotensi menghambat kinerja dari aplikasi SIPP di kantor Pengadilan Negeri Salatiga. Evaluasi resiko merupakan proses evaluasi resiko-resiko berdasarkan tingkat yang palimg tinggi resikonya sampai yang paling rendah resikonya berdasarkan kriteria yang sudah di buat. Pada proses ini nanti berfokus pada evalusai resiko-resiko yang ada pada aplikasi SIPP.

Tahapan kedua setelah Risk Assesment yaitu Risk Treatment dimana pada tahap ini peneliti memberikan rekomendasi atau tindakan terhadap kemungkinan resiko-resiko yang bertujuan utntuk menanganinya atau meminimalisir resiko-resiko yang ada pada aplikasi SIPP. Pada penelitian ini akan dilakukan dengan dua tahap yaitu, pertama peneliti melakukan pencarian informasi yang di butuhkan melalui wawancara langsung dengan narasumber internal Pengadilan Negeri Salatiga, tahap kedua peneliti mengelola data yang sudah di dapat dari wawancara yang kemudian di analisi berdasarkan proses tahapan pada kerangka kerja ISO 31000 .

Metode yang akan penulis gunakan dalam penelitian ini yaitu Case study research, yang dimana metode ini berfokus pada satu objek studi kasus. Sehingga dengan metode ini penulis dapat berfokus pada objek yang diteliti dan dapat mengumpulkan data yang dibutuhkan dengan terarah serta bisa menjawab mengenai permasalahan yang terjadi. Data dalam penelitian ini berupa data primer yang didapatkan dari narasumber langsung yang terkait dengan SIPP ( Sistem Informasi Penelusuran Perkara) Pengadilan Negeri Salatiga. Narasumber dalam penelitian ini ada yaitu salah satu pegawai Pengadilan Negeri Salatiga yang tugasnya 


\section{Journal of Computer and Information Systems Ampera}

Vol. 2, No. 1, January 2021 e-ISSN: 2775-2496

https://journal-computing.org/index.php/journal-cisa/index

mengelola dan mengawasi aplikasi Sistem Informasi Penelusuran Perkara (SIPP).

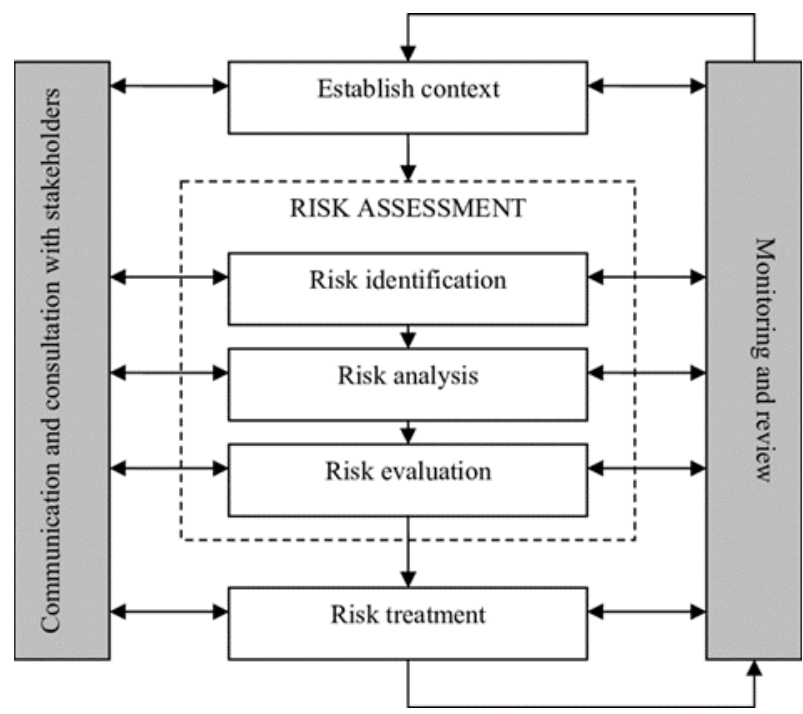

Gambar 1. Tahapan Risk Management

\section{HASIL DAN PEMBAHASAN}

\subsection{Tahap Penilaian Resiko (Risk Assement)}

Pada tahap ini peneliti melakukan penilaian resiko terhadap aplikasi SIPP yang dilakukan sesuai pedoman analisis manajemen resiko ISO 31000. Dimana tahap ini terdapat 3 proses yaitu Identifikasi Resiko (risk identification), Analisis Resiko (risk Analysis), Evaluasi Resiko (risk evaluation).

\subsubsection{Identifikasi Resiko (Risk Identification)}

Pada proses pertama ini yang dilakukan peneliti yaitu mengidentifikasi aset yang terkait dengan aplikasi SIPP yang dilakukan dengan cara mewawancarai salah satu pegawai Pengadilan Negeri Salatiga yang merupakan IT Operation Support. Pada proses ini berfokus pada identifikasi asset dari data, software dan hardware yang berkaitan dengan aplikasi SIPP. 


\section{Journal of Computer and Information Systems Ampera}

Vol. 2, No. 1, January 2021 e-ISSN: 2775-2496

https://journal-computing.org/index.php/journal-cisa/index

Tabel 1. Identifikasi Asset Aplikasi SIPP

\begin{tabular}{ll}
\hline Komponen Sistem Informasi & Asset SIPP \\
\hline Data & Data User, Data Buku \\
Hardware & Server Database, Personal Computer \\
Software & Aplikasi SIPP
\end{tabular}

Setelah dilakukan identifikasi asset yang berkaitan dengan aplikasi SIPP seperti Data, Hardware, Software. Maka selanjutnya melakukan identifikasi kemungkinan resiko-resiko yang akan muncul di sekitar aplikasi SIPP. Disini peneliti mengkelompokan resiko berdasarkan 3 faktor yaitu factor Alam/Lingkungan, Manusia, Sistem dan Infastruktur serta memberikan No ID pada setiap resiko-resiko yang ditemukan.

Tabel 2. Identifikasi Kemungkinan Resiko

\begin{tabular}{ccc}
\hline Faktor & ID & Kemungkinan \\
\hline \multirow{3}{*}{ Alam/Lingkungan } & R01 & Gempa Bumi \\
& R02 & Kebakaran \\
& R03 & Banjir \\
R04 & Petir \\
R05 & Penyalagunaan Hak \\
Manusia & R06 & Akses \\
& R07 & Human Error \\
& R08 & Hecking \\
& R09 & Data/Perangkat keras \\
& R010 & Trouble Web Server \\
Rystem/Infrastruktur & Server Down \\
& R012 & Kerusakan genset \\
& & kantor \\
& R013 & Koneksi Jaringan \\
& R014 & Gangguan \\
& & Kerusakan Hardware \\
& & Data Corrupt
\end{tabular}

Dari tahap indentifikasi resiko ditemukan 14 kemungkinan resiko-resiko yang berasal dari ketiga factor yaitu Alam/Lingkungan, Manusia, System dan Infrastruktur yang berpotensi bisa mengancam proses kinerja aplikasi SIPP. Kemudian kemungkinan resiko-resiko yang sudah teridentifikasi pada table 2 tersebut, dilakukan lagi identifikasi dampak-dampak apa saja 


\section{Journal of Computer and Information Systems Ampera}

Vol. 2, No. 1, January 2021 e-ISSN: 2775-2496

https://journal-computing.org/index.php/journal-cisa/index

yang akan muncul dari kemungkinan resiko-resiko yang sudah di identifikasi. Identifikasi dampak-dampaknya Dapat di lihat pada table 3 berikut.

Tabel 3. Identifikasi Dampak Resiko

\begin{tabular}{|c|c|c|}
\hline ID & Kemungkinan Resiko & Dampak \\
\hline R01 & Gempa Bumi & $\begin{array}{l}\text { Kerusakan infrastruktur dan } \\
\text { Aktitivitas kantor jadi } \\
\text { terganggu }\end{array}$ \\
\hline R02 & Kebakaran & $\begin{array}{l}\text { Kerusakan infrastruktur dan } \\
\text { proses kinerja kantor terhenti }\end{array}$ \\
\hline R03 & Banjir & $\begin{array}{l}\text { Aktivitas kantor jadi } \\
\text { terganggu }\end{array}$ \\
\hline R04 & Petir & $\begin{array}{l}\text { Kerusakan infrastruktur pada } \\
\text { kantor }\end{array}$ \\
\hline R05 & Penyalagunaan Hak Akses & $\begin{array}{l}\text { Data user akan tersadap atau } \\
\text { hak user akan disalah } \\
\text { gunakan }\end{array}$ \\
\hline R06 & Human Error & $\begin{array}{l}\text { Proses layanan kantor tidak } \\
\text { berjalan optimal }\end{array}$ \\
\hline R07 & Hacking & $\begin{array}{l}\text { System mengalami gangguan } \\
\text { atau disadap }\end{array}$ \\
\hline R08 & Pencurian Data/Perangkat Keras & $\begin{array}{l}\text { Kantor mengalami Kerugian } \\
\text { finansial dan kehilangan data. }\end{array}$ \\
\hline R09 & Trouble Web Server & $\begin{array}{l}\text { Pegawai kantor tidak dapat } \\
\text { mengakses aplikasi SIPP } \\
\text { karena mengalami trouble. }\end{array}$ \\
\hline R010 & Server Down & $\begin{array}{l}\text { Server data base bermasalah } \\
\text { mengakibatkan pegawai } \\
\text { kantor tidak bisa mengakses } \\
\text { aplikasi yang berkaitan } \\
\text { dengan server termasuk SIPP. }\end{array}$ \\
\hline R011 & Kerusakan genset kantor & $\begin{array}{l}\text { Sewaktu-waktu listrik padam } \\
\text { pegawai kantor tidak bisa } \\
\text { menggunakan hardware pada } \\
\text { kantor untuk kerja. }\end{array}$ \\
\hline R012 & Koneksi Jaringan Gangguan & $\begin{array}{l}\text { Membutuhkan waktu yang } \\
\text { agak lama untuk Mengakses } \\
\text { aplikasi SIPP. }\end{array}$ \\
\hline R013 & Kerusakan Hardware & $\begin{array}{l}\text { Kinerja kantor jadi terhambat } \\
\text { karena perlu malakukan set } \\
\text { up data di hardware baru }\end{array}$ \\
\hline
\end{tabular}


Journal of Computer and Information Systems Ampera

Vol. 2, No. 1, January 2021 e-ISSN: 2775-2496

https://journal-computing.org/index.php/journal-cisa/index

R014 Data Corrupt

Pegawai tidak bisa mngakses

data karena datanya tidak

valid/corrupt

\subsubsection{Analisis Resiko (Risk Analysis)}

Setelah melakukan identifikasi kemungkinan resiko-resiko beserta dampak-dampaknya, kemudian selanjutnya melakukan proses analisis resiko. Pada tahap ini di lakukan analisis tehadap kemungkinan resikoresiko yang sebelumnya sudah di identifikasi, pada tahap ini terdapat 2 table kriteria yaitu Likehood dan Impact yang menjadi acuan untuk tahap analisis resiko. pada tabel 4 terdapat table kriteria likehood yang dimana table tersebut terdapat 5 kriteria yang dibedakan berdasarkan seberapa banyak kemungkinan resiko dapat terjadi dalam kurun waktu tertentu.

Tabel 4. Kriteria Likelihood

\begin{tabular}{cccc}
\hline Nilai & Kriteria & Keterangan & $\begin{array}{c}\text { Frekuensi } \\
\text { Kejadian }\end{array}$ \\
\hline 1 & Rare & Resiko tersebut hampir tidak pernah & $>2$ tahun \\
& & terjadi & $1-2$ tahun \\
2 & Unlikely & Resiko tersebut jarang terjadi & $7-12$ bulan \\
3 & Possible & Resiko tersebut kadang terjadi & $4-6$ bulan \\
4. & Likely & Resiko tersebut sering terjadi & $1-3$ bulan \\
5 & Certain & Resiko tersebut pasti terjadi & \\
\hline
\end{tabular}

Kemudian pada table 5 terdapat table nilai impact yang merupakan dampak jika kemungkinan resiko-resiko tersebut terjadi pada kantor Pengadilan Negeri Salatiga. Di dalam table penilaian impact terdapat 5 kriteria dampak yang mungkin terjadi, yang dibedakan berdasarkan dampak yang tidak berpengaruh bagi kantor Pengadilang Negeri Salatiga hingga dampak yang paling mempengaruhi kinerja kantor.

Tabel 5. Kriteria Impact

\begin{tabular}{|c|c|c|}
\hline Nilai & Kriteria & Keterangan \\
\hline 1. & Insignificant & Tidak mengganggu aktivitas kantor \\
\hline 2. & Minor & $\begin{array}{l}\text { Aktivitas kantor sedikit terhambat namun aktivitas } \\
\text { inti perpustakaan tidak mengganggu }\end{array}$ \\
\hline 3. & Moderate & $\begin{array}{l}\text { Menyebapkan gangguan pada proses kinerja } \\
\text { sehingga jalannya aktivitas perpustakaan terhambat }\end{array}$ \\
\hline
\end{tabular}




\section{Journal of Computer and Information Systems Ampera}

Vol. 2, No. 1, January 2021 e-ISSN: 2775-2496

https://journal-computing.org/index.php/journal-cisa/index

4. Major Menghambat hampir seluruh aktivitas kantor

5. Catasirophic Akivitas kantor berhenti karena proses kinerja mengalami ganguan total

Setelah menentukan nilai Likelihood pada tabel 4 dan impact pada tabel 5 , selanjutnya melakukan penilaian terhadap kemungkinan resiko-resiko yang sudah di identifikasikan pada tahap sebelumnya. Dari 14 kemungkinan resiko-resiko yang sudah diidentifikasikan tersebut masingmasing resiko ditentukan nilai Likelihood dan nilai impact nya yang acuannya sudah dibuat pada tabel 4 dan tabel 5. Tabel penilaiann terhadap kemungkinan resiko-resiko bisa di lihat pada tabel 6 berikut.

Tabel 6. Penilaian Terhadap Kemungkinan Resiko

\begin{tabular}{|c|c|c|c|c|}
\hline Faktor & ID & $\begin{array}{c}\text { Kemungkinan } \\
\text { Resiko }\end{array}$ & Likelihood & Impact \\
\hline \multirow{4}{*}{ Alam/Lingkungan } & R01 & Gempa Bumi & 1 & 5 \\
\hline & R02 & Kebakaran & 2 & 5 \\
\hline & R03 & Banjir & 1 & 1 \\
\hline & R04 & Petir & 1 & 1 \\
\hline \multirow{4}{*}{ Manusia } & R05 & $\begin{array}{c}\text { Penyalagunaan } \\
\text { Hak Akses }\end{array}$ & 1 & 1 \\
\hline & R06 & Human Error & 1 & 1 \\
\hline & R07 & Hacking & 2 & 4 \\
\hline & R08 & $\begin{array}{c}\text { Pencurian } \\
\text { Data/Perangkat } \\
\text { Keras }\end{array}$ & 1 & 1 \\
\hline \multirow{6}{*}{ System/Infrastruktur } & R09 & $\begin{array}{l}\text { Trouble Web } \\
\text { Server }\end{array}$ & 1 & 2 \\
\hline & R010 & Server Down & 2 & 2 \\
\hline & R011 & $\begin{array}{l}\text { Kerusakan } \\
\text { genset kantor }\end{array}$ & 1 & 3 \\
\hline & R012 & $\begin{array}{l}\text { Koneksi } \\
\text { Jaringan } \\
\text { Gangguan }\end{array}$ & 2 & 5 \\
\hline & R013 & $\begin{array}{c}\text { Kerusakan } \\
\text { Hardware }\end{array}$ & 2 & 5 \\
\hline & R014 & Data Corrupt & 1 & 2 \\
\hline
\end{tabular}

\subsubsection{Evaluasi Resiko (Risk Evaluation)}

Pada proses terakhir yaitu evaluasi resiko (risk evaluation) untuk tahap risk assessment (penilaian resiko). Pada proses ini mengunakan acuan 


\section{Journal of Computer and Information Systems Ampera}

Vol. 2, No. 1, January 2021 e-ISSN: 2775-2496

https://journal-computing.org/index.php/journal-cisa/index

berupa tabel matrix evaluasi resiko yang berdasarkan pada pedoman kerangka kerja ISO 31000 dimana dalam tabel matrix evaluasi resiko di bedakan menjadi 3 risk level yaitu low, medium, dan high. Pada tabel. 7 dibawah ini merupakan tabel matrix evaluasi resiko yang sudah di tentukan risk level berdasarkan likelihood dan impact nya.

Tabel 7. Matrix Evaluasi Resiko

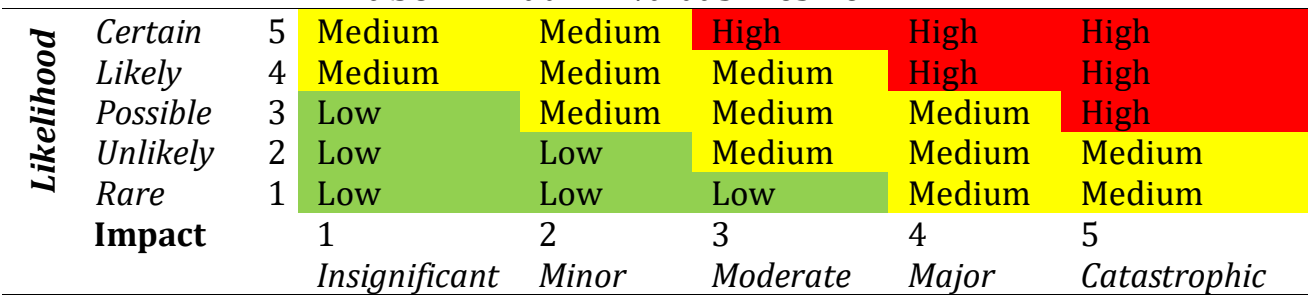

Setelah itu kemungkinan resiko-resiko yang sudah di tentukan nilai likelihood dan impact nya akan di masukan kedalam matrix evaluasi resiko disesuaikan dengan pemetaan pada tabel tersebut. Pada tabel. 8 dibawah ini merupakn hasil dari kemungkinan resiko-resiko yang sudah di masukan kedalam tabel matrix evaluasi resiko sesuai dengan kriteria likelihood dan kriteria impact yang sudah ditentukan pada tahap sebelumnya.

Table 8. Matrix Evaluasi Resiko Berdasarkan nilai likelihood dan impact

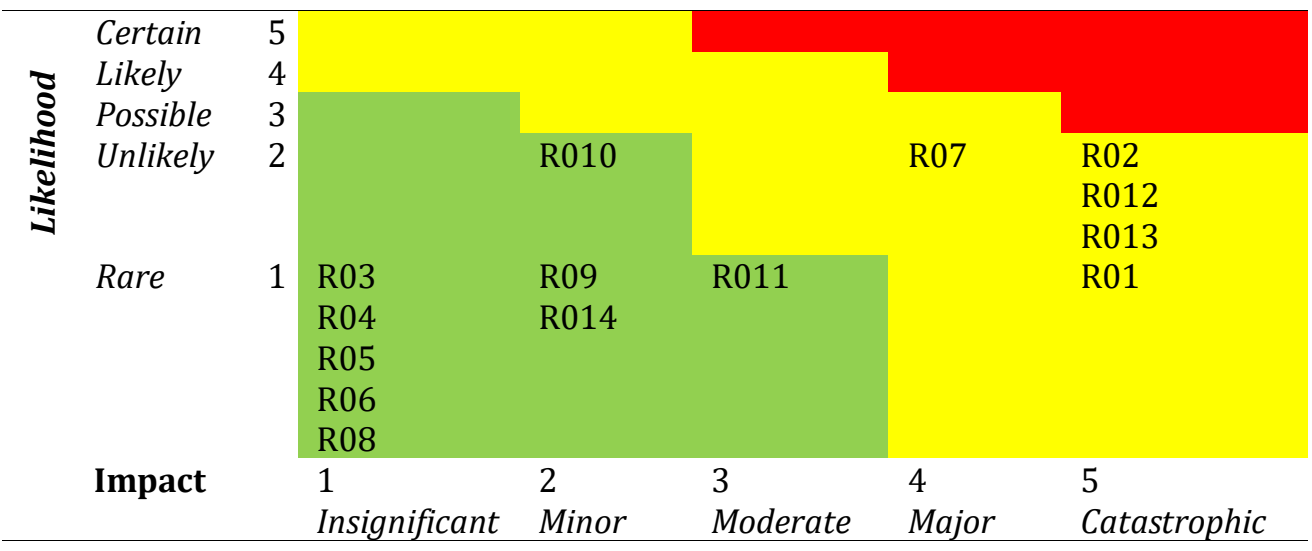

Selanjutnya setelah semua kemungkinan resiko-resiko yang sudah teridentifikasi di masukan kedalam matrix evaluasi resiko yang 


\section{Journal of Computer and Information Systems Ampera}

Vol. 2, No. 1, January 2021 e-ISSN: 2775-2496

https://journal-computing.org/index.php/journal-cisa/index

disesuaikan dengan nilai likelihood dan impact nya pada table 9 berikut akan dikelompokan dari 14 kemungkinan resiko-resiko yang ada dan di sesuaikan dengan tingkat risk level nya high, medium dan low berdasarkan data yang ada di table 8 sebelumnya.

Table 9. Tabel Ketingkatan risk level berdasarkan masing-masing resiko

\begin{tabular}{|c|c|c|c|c|}
\hline ID & Kemungkinan Resiko & Likelihood & Impact & Risk level \\
\hline R02 & Kebakaran & 2 & 5 & Medium \\
\hline R013 & Kerusakan Hardware & 2 & 5 & Medium \\
\hline R012 & Koneksi Jaringan Gangguan & 2 & 5 & Medium \\
\hline R01 & Gempa Bumi & 1 & 5 & Medium \\
\hline R07 & Hacking & 2 & 4 & Medium \\
\hline R011 & Kerusakan genset kantor & 1 & 3 & Low \\
\hline R010 & Server Down & 2 & 2 & Low \\
\hline R09 & Trouble Web Server & 1 & 2 & Low \\
\hline R014 & Data Corrupt & 1 & 2 & Low \\
\hline R03 & Banjir & 1 & 1 & Low \\
\hline R04 & Petir & 1 & 1 & Low \\
\hline R05 & Penyalagunaan Hak Akses & 1 & 1 & Low \\
\hline R06 & Human Error & 1 & 1 & Low \\
\hline R08 & $\begin{array}{c}\text { Pencurian Data/Perangkat } \\
\text { Keras }\end{array}$ & 1 & 1 & Low \\
\hline
\end{tabular}

Hasil pada proses evaluasi resiko terdapat 14 kemungkinan resiko yang sudah di kelompokkan berdasarkan risk levelnya bisa di lihat pada tabel 9 diatas. Pada hasil yang ada pada tabel tersebut tidak terdapat kemungkinan resiko dengan risk level high. Sedangkan pada tingkat risk level medium terdapat 5 kemungkinan resiko yaitu : R013(kerusakkan hardware), R012(koneksi jaringan gangguan), R02(kebakaran), R01(gempa bumi), R07 (hacking). Serta terdapat 9 kemungkinan resiko pada tingkat risk level low yaitu : R011(kerusakan genset kantor), R010(server down), R09(trouble web server), R014(data corrupt), R03(banjir), R04(petir), R05(penyalagunaan hak akses), R06(human error), R08(pencurian data/perangkat keras).

\subsection{Perlakuan Resiko(risk Treatment)}

Setelah melakukan tahapan risk assement yang di delamnya terdapat 3 proses tahapan yaitu risk identification, risk analysis, dan risk evaluation maka selanjutnya akan masuk ke tahapan seleanjutnya yaitu proses risk treatment yang dimana pada tahap ini peneliti memberikan tindakan atau 


\section{Journal of Computer and Information Systems Ampera}

Vol. 2, No. 1, January 2021 e-ISSN: 2775-2496

https://journal-computing.org/index.php/journal-cisa/index

masukan terhadap kemungkinan resiko-resiko yang sudah di identifikasi dan sudah di kelompokkan berdasarkan risk level pada tabel 9 sebelumnya. Pada tabel 10 di bawah ini merupakan usulan atau tindakkan dari peneliti terhadap resiko-resiko yang ada. Sehingga usulan tersebut dapat digunakan oleh kantor Pengadilan Negeri Salatiga untuk melakukan pencegaan atau setidaknya meminimalisir terhadap kemungkinan resiko yang ada.

Tabel 10. Usulan Perlakuan Terhadap Resiko

\begin{tabular}{|c|c|c|c|}
\hline ID & Kemungkinan Resiko & Risk level & Usulan terhadap resiko \\
\hline R02 & Kebakaran & Medium & $\begin{array}{l}\text { Menyediakan alat untuk } \\
\text { pemadam api seperti } \\
\text { trolley, hydrant dan memasang } \\
\text { sprinkler di ruang tertentu yang } \\
\text { dianggap vital atau sangat } \\
\text { penting bagi kantor. }\end{array}$ \\
\hline R013 & Kerusakan Hardware & Medium & $\begin{array}{l}\text { Harus di adakan pengecekan } \\
\text { hardware setiap bulan atau } \\
\text { setiap } 3 \text { bulan agar kalau ada } \\
\text { hardware yang rusak bisa di } \\
\text { perbaiki oleh teknisi dan } \\
\text { melakukan pencadangan } \\
\text { hardware agar kalau ada } \\
\text { hardware yang sudah tidak bisa } \\
\text { di perbaiki bisa diganti dengan } \\
\text { yang baru. }\end{array}$ \\
\hline R012 & $\begin{array}{l}\text { Koneksi Jaringan } \\
\text { Gangguan }\end{array}$ & Medium & $\begin{array}{l}\text { Jika jaringan terjadi ganguan } \\
\text { laporkan kepada bagian } \\
\text { jaringan. } \\
\text { Mengganti ISP (Internet Service } \\
\text { Provider) baru jika ganguan } \\
\text { jaringannya parah sekali. }\end{array}$ \\
\hline R01 & Gempa Bumi & Medium & $\begin{array}{l}\text { Menyediakan server cadangan } \\
\text { di tempat lain. Atau } \\
\text { menyediakan tempat yang } \\
\text { cukup aman untuk perangkat- } \\
\text { perangkat yang menunjang } S A P \\
\text { pada kantor tersebut. }\end{array}$ \\
\hline R07 & Hacking & Medium & $\begin{array}{l}\text { Meningkatkan system security } \\
\text { pada kantor. Seperti protect } \\
\text { with password yang dimana } \\
\text { semua akses yang menyangkut } \\
\text { ke jaringan maupun data harus }\end{array}$ \\
\hline
\end{tabular}




\section{Journal of Computer and Information Systems Ampera}

Vol. 2, No. 1, January 2021 e-ISSN: 2775-2496

https://journal-computing.org/index.php/journal-cisa/index

R011 Kerusakan genset Low

R010 Server Down

R09 Trouble Web Server Low

R014
Data Corrupt di jaga dengan nama pengguna dan kata sandi yang unik. Ada juga Design safe system yang dimana jauhkan akses yang tidak perlu pada hardware maupun software kantor agar mencegah mudahnya peretas pada system.

Segera melakukan pengadakan genset baru yang kualitasnya lebih bagus dari genset sebelumnya dan Menyediakan UPS (Uninterruptible Power Supply) pada perangkatperangkat tertentu yang menunjang SAP pada kantor. Alat ini berguna untuk melindungi perangkat dari arus listrik yang tidak stabil seperti listrik padam secara tiba-tiba dan sebaginya.

Low Melakukan pengecekan secara berkala tehadap data base dari aplikasi SIPP atau data base utama kantor.

Melakukan pemberitahuan kepada pegawai atau user kalau web server sedang trouble. Pemberitahuan tersebut bisa berguna buat pegawai atau user agar pegawai bisa mengerjakan pekerjaan yang lain dulu. Serta segera melakukan perbaikan dan pengecekan hal apa yang menyebapkan trouble web server.

Low Melakukan backup data secara berkala dan melakukan pembersihan pada PC menggunakan aplikasi yang recommended atau scan mengguakan anti virus pada PC agar mencegah munculnya virus pada PC yang nanti bisa 


\section{Journal of Computer and Information Systems Ampera}

Vol. 2, No. 1, January 2021 e-ISSN: 2775-2496

https://journal-computing.org/index.php/journal-cisa/index

\begin{tabular}{|c|c|c|c|}
\hline & & & $\begin{array}{l}\text { menyebapkan data corrupt } \\
\text { karena virus tersebut. Lakukan } \\
\text { hal tersebut secara berkalah. }\end{array}$ \\
\hline R03 & Banjir & Low & $\begin{array}{l}\text { Menyediakan tempat atau } \\
\text { ruang untuk perangkat- } \\
\text { perangkat penunjang SAP yang } \\
\text { dianggap vital bagi kantor yang } \\
\text { sekiranya aman dari banjir }\end{array}$ \\
\hline R04 & Petir & Low & $\begin{array}{l}\text { Menyediakan alat penangkal } \\
\text { petir agar sewaktu-waktu kalau } \\
\text { ada petir tidak terjadi hal yang } \\
\text { tidak diinginkan terhadap } \\
\text { perangkat-perangkat yang } \\
\text { mendukung } S A P \text { pada kantor. }\end{array}$ \\
\hline R05 & $\begin{array}{c}\text { Penyalagunaan Hak } \\
\text { Akses }\end{array}$ & Low & $\begin{array}{l}\text { Mengadakan maintenance } \\
\text { password secara berkala. } \\
\text { Memberikan konfirmasi login } \\
\text { yag berkaitan dengan pribadi } \\
\text { user } \\
\text { Memasang CCTV pada ruangan } \\
\text { kerja kantor. }\end{array}$ \\
\hline R06 & Human Error & Low & $\begin{array}{l}\text { Melakukan pelatihan atau } \\
\text { training sebelumnya kepada } \\
\text { pegawai atau user terhadap } \\
\text { penggunaan aplikasi SIPP agar } \\
\text { tidak terjadi kesalahan atau } \\
\text { bingung pada } \\
\text { menggunakannya. }\end{array}$ \\
\hline R08 & $\begin{array}{c}\text { Pencurian } \\
\text { Data/Perangkat Keras }\end{array}$ & Low & $\begin{array}{l}\text { Memasang CCTV pada bagian- } \\
\text { bagian ruangan yang ada } \\
\text { perangkat kerasnya dan kalau } \\
\text { bisa melakukan maintenance } \\
\text { password agar tidak terhadi } \\
\text { pencurian data. }\end{array}$ \\
\hline
\end{tabular}

\section{KESIMPULAN}

Analisi manajemen resiko yang menggunakan International Organization Standardization atau ISO 31000 pada aplikasi SIPP di kantor Pengadilan Negeri Salatiga kelas 1B telah dilaksanakan. Analisi manajemen resiko di laksanakan dengan prosedur yag ada pada ISO 31000 yang dimulai dari tahapan risk assessment yang dimana tahap itu ada 3 proses atau langkah yaiu risk identification, risk analysis, dan risk 


\section{Journal of Computer and Information Systems Ampera}

Vol. 2, No. 1, January 2021 e-ISSN: 2775-2496

https://journal-computing.org/index.php/journal-cisa/index

evaluation. Selanjutnya setelah 3 proses itu sudah di lewati, masuk pada tahap terakhir yaitu risk treatment yang dimana tahap itu peneliti membuat saran atau perlakuan terhadap kemungkinan resiko yang ada pada aplikasi SIPP.

Dari hasil penelitian analisis resiko terdapat 14 kemungkinan resiko yang dapat mengganggu kinerja dari aplikasi SIPP di kantor Pengailan Salatiga. Dimana ke 14 resiko tersebut tidak ada kemungkinan resiko yang memiliki tingkat risk level high. Kemudian terdapat 5 kemungkinan resiko yang tingkat risk level medium yaitu : : R013(kerusakkan hardware), R012(koneksi jaringan gangguan), R02(kebakaran), R01(gempa bumi), R07(hacking). Serta terdapat 9 kemungkinan resiko pada tingkat risk level low yaitu : R011(kerusakan genset kantor), R010(server down), R09(trouble web server), R014(data corrupt), R03(banjir), R04(petir), R05(penyalagunaan hak akses), R06(human error), R08(pencurian data/perangkat keras). Dengan demikian hasil penelitian ini dapat dipergunakan Pengadilan Negeri Salatiga untuk mengatur Standard Operasional Procedure atau untuk meminimalisir kemungkinan resiko-resiko yang akan terjadi pada SAP kantor kemudian hari.

\section{DAFTAR PUSTAKA}

[1] Angraini and I. D. Pertiwi, "Analisa Pengelolaan Risiko Penerapan Teknologi Informasi Menggunakan ISO 31000," J. Ilm. Rekayasa dan Manaj. Sist. Inf., vol. 3, no. 2, pp. 70-76, 2017, [Online]. Available: http://ejournal.uinsuska.ac.id/index.php/RMSI/article/view/4317.

[2] G. W. Lantang, A. D. Cahyono, and M. N. N. Sitokdana, "Analisis Risiko Teknologi Informasi Pada Aplikasi Sap Di Pt Serasi Autoraya Menggunakan Iso 31000," Sebatik, vol. 23, no. 1, pp. 36-43, 2019, doi: $10.46984 /$ sebatik.v23i1.441.

[3] F. A. Alvian et al., "Manajemen risiko pada laboratorium integrasi universitas islam negeri sunan ampel surabaya menggunakan iso 31000 of sunan ampel surabaya using iso 31000 ," vol. 12 , no. 1 , pp. 56-67, 2020.

[4] Wahidmurni, "PEMAPARAN METODE PENELITIAN KUALITATIF Oleh:," J. Sains dan Seni ITS, vol. 6, no. 1, pp. 51-66, 2017.

[5] S. Agustinus, A. Nugroho, and A. D. Cahyono, "Analisis Risiko Teknologi Informasi Menggunakan ISO 31000 pada Program HRMS," J. RESTI (Rekayasa Sist. dan Teknol. Informasi), vol. 1, no. 3, 


\section{Journal of Computer and Information Systems Ampera}

Vol. 2, No. 1, January 2021 e-ISSN: 2775-2496

https://journal-computing.org/index.php/journal-cisa/index

pp. 250-258, 2017, doi: 10.29207/resti.v1i3.94.

[6] D. L. Ramadhan, R. Febriansyah, and R. S. Dewi, "Analisis Manajemen Risiko Menggunakan ISO 31000 pada Smart Canteen SMA XYZ," JURIKOM (Jurnal Ris. Komputer), vol. 7, no. 1, p. 91, 2020, doi: 10.30865/jurikom.v7i1.1791.

[7] F. Asmin, "Analisis Resiko Implementasi Kegiatan Pengembangan Masyarakat Sekitar Hutan Di Sumatera Barat 194," J. Sist. (Sistem Informasi), vol. 8, pp. 194-203, 2019. 